\title{
Peace and Biotechnology in the Middle East
}

\author{
JOH N HODGSON
}

\section{John Hodgson is articles editor and European publishing manager of \\ Bio/Technology.}

\section{$T$}

he Israel-Palestine accord that has surprised the world could be the best thing to happen to biotechnology in the Middle East in a very long time. Although the accord is only the first step, and still a very small one, on the path toward peace and stability in the region, it will allow Israel to participate more fully in the industrial revoution that biotechnology promises.

Israel is touting for inward investment, especially from the United States and Europe, for various industry sectors, particularly electronics and biotechnology. A small part of a $\$ 1.0$ million account won by public relations company, Hill \& Knowlton, from the Israeli government for that purpose, took me, economy class, to assess the country's prospects in biotechnology.

Israel has worked hard to develop a presence in biotechnology. Already, most of the biotechnology in the Middle East takes place in Israel (although that might not be much of a boast). Israel also has a history of political inclination towards biotechnology: its first President, Chaim Weismann, and its fourth, Ephraim Katzir were practicing biologists: Weismann will always be associated with the development of the acetobutanol fermentation process in the 1940s while Katzir's interests were (and are) in protein structure and interaction. Katzir is still active today in biotechnology; he has forged the links necessary to provide political allies for Israel's compact and wellorganized bioindustry association. The work of the association has led, among other things, to increased funding in the life sciences, and measures that allow researchers to devote time to commercialization of their ideas without relinquishing tenure or other links with their universities.

Despite these measures, however, Israel cannot yet be said to be involved in all aspects of biotechnology. Israel's model of biotechnology is incomplete. It has science and technology a-plenty. It has the highest density of professional biologists anywhere in the world. Many of them formerly lived in North America or in Europe and gained their training before emigrating to Israel. More recently, there has a been a large influx of different, perhaps complementary, skills and experience from the former Soviet Union and Eastern Europe. Furthermore, according to government officials, the Israeli science base is relatively cheap-labor costs of qualified personnel are perhaps two-thirds of those in the most developed nations of the East and West.

Israel's science is supported by a network of home- grown equipment and reagent companies, whose presence ensures a continuing supply regardless of the temperature in the international political arena surrounding Israel.

Israel's biotechnology has also attracted private investment, perhaps because an investment dollar can be stretched one-and-a-half times further. That investment, largely channeled through U.S. investors like David Blech, supports the activities of R\&D startup companies such as Bio-Technology General (Rehovot), Pharmos (Rehovot) and Ecogen Israel (Jerusalem). Investment by U.S. companies is encouraged by organizations like BIRD (the Bilateral Israeli R\&D Fund), which uses a variety of favorable tax and location incentive packages to funnels funds directly to collaborating Israeli partners.

Israel's regulations are also encouraging for biotechnology. It is said that new drugs can be made available to broad patient populations in Israel many months or even years before they obtain approval from the Food and Drug Administration (Bethesda, MD).

What Israeli companies do not have, however, is a readily accessible direct route to large markets, making it difficult to generate revenues from manufacturing rather than technology development. Israel's local market is limited by the politics of the Middle East. The Arab embargo of goods produced in Israel may dissuade many multinational companies from establishing manufacturing facilities. And there are the effects, real or perceived, of political instability on the supply of goods.

On the positive side, Israel is the only country in the world with free-trade agreements with both of the world's two largest trading blocs, the United States and the European Community. This says much about the lack of progress in the Uruguay round of the General Agreement on Tariffs and Trade (GATT) - and, perhaps, about international trade cooperation in general. The result is that, for certain products, Israel has become the world's tax collector: goods shipped from one trading bloc and "finished" in Israel with sufficient value added can be shipped out again —as "Israeli produce" - to the other bloc. Import tariffs on direct trade ensure that the same materials are more expensive than those that pass through Israel. Israel, unsurprisingly, is now trying to establish a similar free-trade agreement with its trading partners further east in Asia.

But this brokerage cannot last nor can it sustain a nation as ambitious as Israel, which already has in place many of the right elements for national success in biotechnology. Now perhaps, Israel and its companies can look forward toexploring the markets for high-technology products that a greater stability brings. 